\title{
Lumbar Epidural Varicose Vein: Early Neurological Improvement and Late Radiological Full Recovery with Surgery; The Importance of Magnetic Resonance Imaging in Follow-Up
}

\author{
Lomber Epidural Venöz Varis: Cerrabi ile Erken Nörolojik İileşme ve \\ Geç Radyolojik Tam Düzelme; İzlemde Manyetik Rezonans \\ Görüntülemenin Önemi
}

Haydar CELIK ${ }^{1}$, Yavuz ERDEM ${ }^{1}$, Mete KARATAY ${ }^{1}$, Mehmet YORUBULUT ${ }^{2}$, Tansu GURSOY ${ }^{1}$, Idris SERTBAS $^{1}$, Mehmet Akif BAYAR ${ }^{1}$

${ }^{1}$ Ministry of Health, Ankara Training and Research Hospital, Department of Neurosurgery, Ankara, Turkey

${ }^{2}$ Acıbadem Hospital, Department of Radiology, Ankara, Turkey

Corresponding Author: Haydar CELIK / E-mail: dr_haydarcelik@hotmail.com

\begin{abstract}
A lumbar epidural varicose vein is a rare clinical condition that can lead to neurological deficits. 3 types of lumbar epidural varicose veins were described according to the magnetic resonance imaging (MRI) findings: Type 1 is a thrombosed dilated epidural vein, type 2 is a non-thrombosed dilated epidural vein and type 3 is a sub-membraneous epidural hematoma. Enlarged epidural venous plexuses must be decompressed if they have lead to a neurological deficit. Surgical treatment is by excision or disrupting the cyst's integrity. We present a case of lumbar epidural varicose vein that was surgically treated twice and showed no radiological change despite the disruption of integrity with a partial excision. The lesion spontaneously and completely disappeared in the late period. We emphasize the importance of MRI in follow-up.
\end{abstract} KEYWORDS: Lumbar epidural varicose vein, Magnetic resonance imaging, Surgery

öz

Lomber epidural varis nadir görülen ve hastalarda nörolojik defisitlere yol açabilen klinik bir durumdur. Lomber epidural varislerin manyetik rezonans görüntüleme (MRG) bulgularına göre 3 tipi tanımlanmıştır:Tip 1: tromboze dilate epidural ven Tip 2: nontromboze dilate epidural ven Tip 3: submembranöz epidural hematom. Genişlemiş epidural venöz pleksuslar hastalarda nörolojik defisite yol açtıysa mutlaka dekomprese edilmelidir Cerrahi tedavi ile eksize edilerek veya bütünlükleri bozularak hastaların cerrahi kondisyonları düzeltilebilir. Yazımızda iki kez cerrahi olarak tedavi edilen ve parsiyel eksizyonla bütünlüğü bozulmasına rağmen radyolojik olarak değişim göstermeyen ancak geç dönemde spontan tamamen ortadan kaybolan bir lomber epidural varis olgusu sunduk ve MRG'nin takipteki önemini vurgulamaya çalıştık.

ANAHTAR SÖZCÜKLER: Lomber epidural venöz varis, Manyetik rezonans görüntüleme, Cerrahi

\section{INTRODUCTION}

The incidence of a lumbar epidural varicose vein is $0.067 \%$ $1.2 \%$ in various studies (5). It causes location-related symptoms and can lead to radiculopathy or myelopathy. Surgical treatment is with laminectomy, excision or thermocoagulation with bipolar cautery. Abdominal bleeding can be encountered during surgery $(1,5)$.

We present a lumbar epidural varicose case at the L1-2 level that caused severe weakness in the left leg. Total laminectomy and partial excision were performed. Despite clinical recovery, the lesion dimensions did not change on magnetic resonance imaging (MRI) in the early period. The patient was taken to surgery for bipolar thermocoagulation but follow-up MRI showed no decrease in lesion size. The lesion spontaneously disappeared in 3rd month follow-up MRI. We emphasize in this article that radiological recovery can be delayed in epidural varicose vein treated surgically and that MRI followup is useful as the lesions can become symptomatic again postoperatively, although not seen in our case.

\section{CASE REPORT}

A 54-year-old patient presented to our clinic with symptoms of bilateral lower extremity numbness, weakness in the left leg and inability to walk for 10 days. Deep tendon reflexes (DTRs) were normo-active and the distal pulses were patent. A lesion reported as an epidural mass or hematoma at the level of L1-2 was seen on MRI (Figure 1A, B). The patient 
underwent emergency surgery. L1 laminectomy and bilateral L2 foraminotomy were performed. A biopsy was taken from the enlarged venous structure at the epidural region and bipolar cauterization was performed for the lesion. The deficits improved in the postoperative early period. No regression was seen in the size of the venous structure at the follow-up MRI (Figure 2A, B). Postoperative spinal selective angiography was normal. The pathology result was a degenerated venous plexus containing erythrocytes adjacent to the vessel structure and fibrin in the lumen together with degenerated connective tissue elements. The patient was again operated and bipolar thermocoagulation repeated but no lesion shrinkage was seen on the follow-up MRI (Figure $3 \mathrm{~A}, \mathrm{~B})$. The lesion had disappeared on the postoperative $3^{\text {rd }}$ month follow-up MRI (Figure 4A, B) and the patient had no neurological deficit.

\section{DISCUSSION}

Lumbar epidural varicose vein is a pathological structure that develops as a result of vertebral venous plexus enlargement.
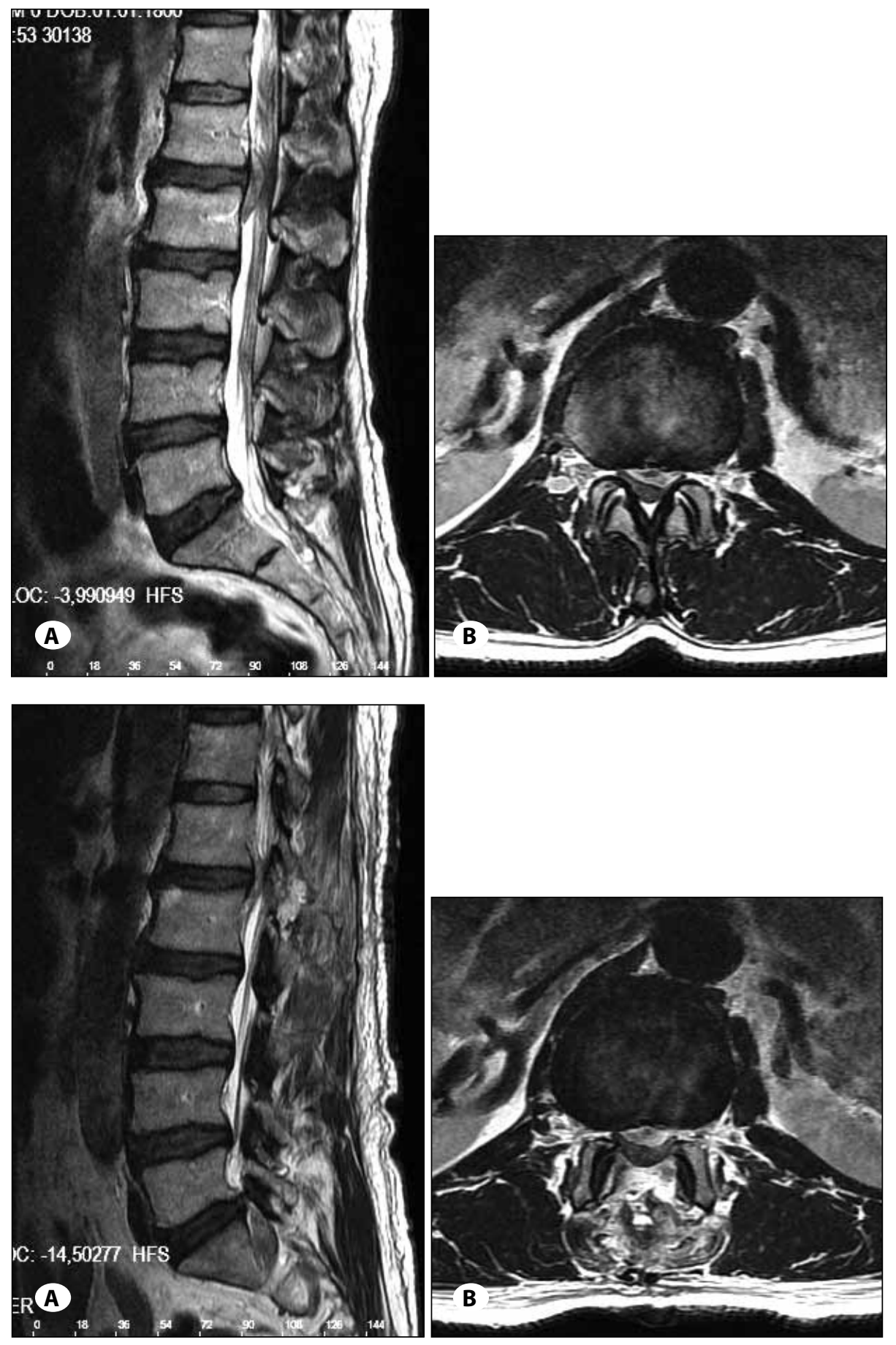

Figure 1: A) T2A sagittal and B) T2A axial MRI images: A fusiform mass lesion with mild hypertintense signal located in the midline-left posterolateral and compressing the thecal sac at the anterior epidural distance at the L1-2 disc level is seen.
Figure 2: A) T2A sagittal and B) T2A axial MRI images: The defined lesion and other findings are similarly seen. The relevant posterior elements have a defective appearance secondary to surgery. 
Although the formation mechanisms are not clearly known, it is thought to be an increase in venous pressure in venous structures lacking valves and a blockage of flow towards the vena cava (6). Intraabdominal pressure increases due to reasons such as pregnancy, intraabdominal mass or obesity can increase inferior vena cava pressure and then dilate the spinal epidural venous plexus and compress the cord or nerve roots $(2,7)$.

Hanley et al. have described 3 types of lumbar epidural varicose veins according to the MRI findings: Type 1 is a thrombosed dilated epidural vein, type 2 is a non-thrombosed dilated epidural vein and type 3 is a sub-membraneous epidural hematoma (6). Our case was consistent with type 2.

Lumbar epidural varicose veins that cause myelopathy and radiculopathy are quite rare. They are usually diagnosed intraoperatively (9). Thrombosed epidural varicose veins are usually confused with herniated nucleus pulposus on preoperative MRI (10). An epidural varicose vein thought to be cystic nerve sheath tumor and operated on has been reported (1). A patient who was first diagnosed with nerve

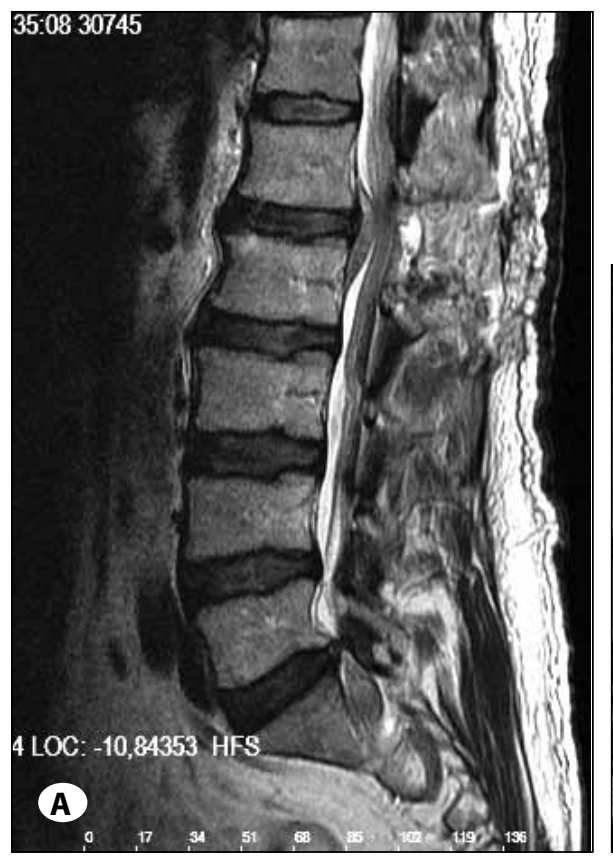

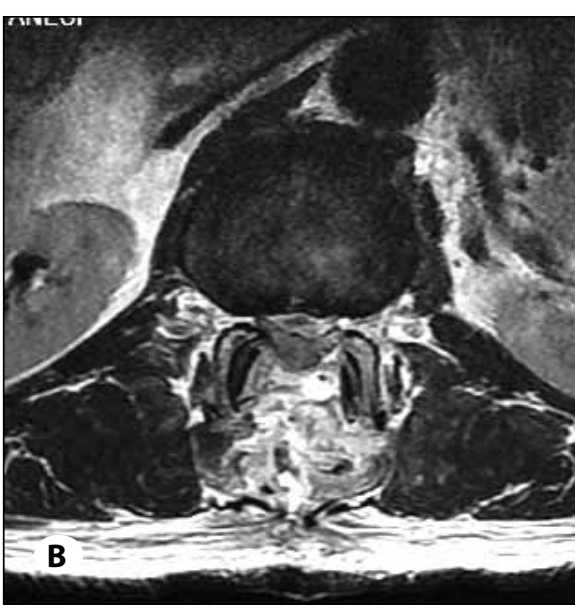

Figure 3: A) $T 2 A$ sagittal and B) $T 2 A$ axial MRI images: Defined lesion has become smaller but is still present.

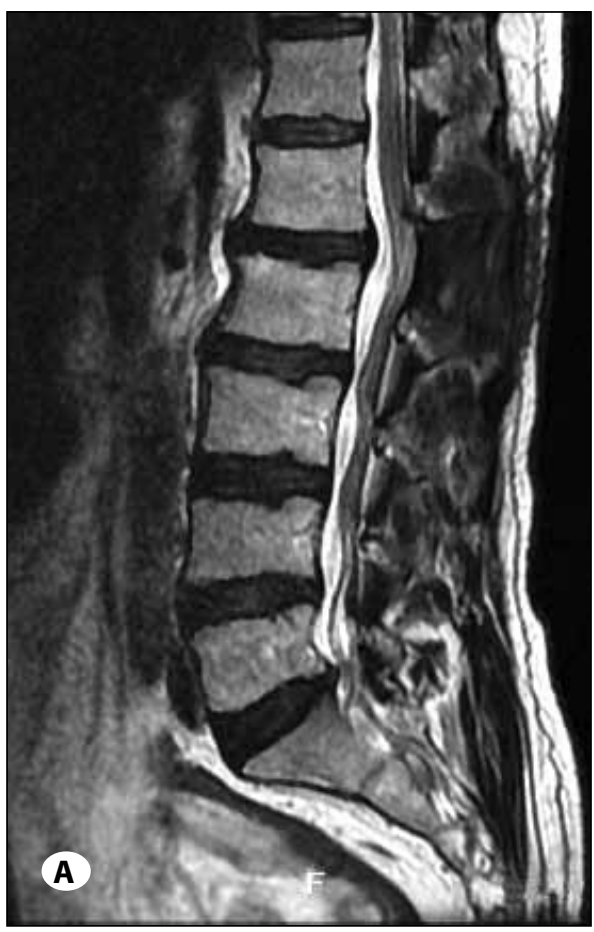

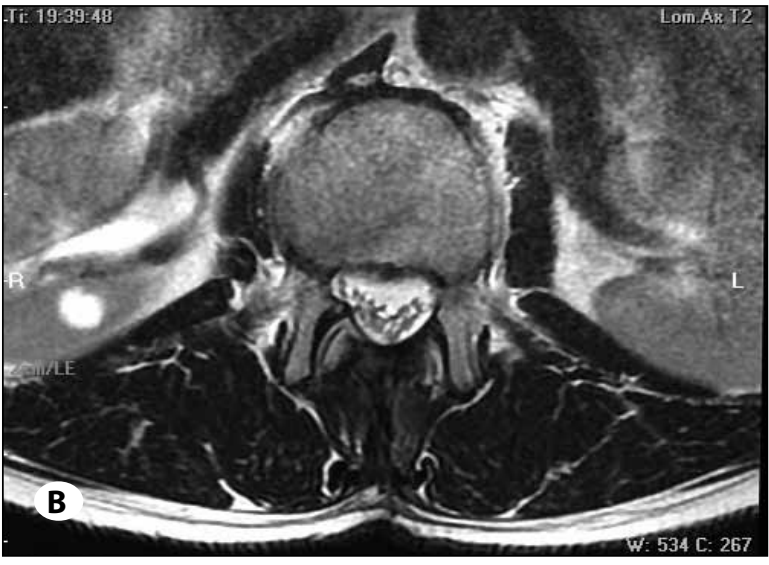

Figure 4: A) T2A sagittal and B) T2A axial MRI images: The epidural lesion at the L1-2 disc level seen on previous examinations has completely disappeared. 
sheath tumor was diagnosed with epidural varicose vein by monitoring the changes in MRI with breath holding and valsalva maneuvers when the patient did not accept surgery (8). Although cases causing radiculopathy are mostly reported $(2,5)$ these lesions have been shown to lead to neurogenic claudication in a case without spinal stenosis (3).

The natural course of epidural varicose veins is not known well. A female patient who defined right sciatalgia during exercise was diagnosed with epidural varicose vein with MRI, and shrinkage in the size of the lesion and regression in symptoms were reported on follow-up MRIs taken every 2 weeks (12).

The most appropriate treatment for lumbar epidural varicose veins is surgery if they are symptomatic. However, treatment can be conservative if there are no significant neurological findings $(4,12)$. Laminectomy, excision and bipolar thermocoagulation can be used in surgery (11). Our patient's symptoms and neurological deficit improved with partial varicose excision and total laminectomy.

\section{CONCLUSION}

Enlarged epidural venous plexuses must be decompressed if they have lead to a neurological deficit. Clinical recovery is possible with decompression. However, the radiological disappearance of the lesion is important in terms of the clinical condition not recurring. The patients should therefore be frequently followed-up with MRIs even if decompression provides clinical recovery.

\section{REFERENCES}

1. Aoyama T, Hida K, Akino M, Yano S, Saito H, Iwasaki Y: Radiculopathy caused by lumbar epidural venous varix: Case report. Neurol Med Chir (Tokyo) 48(8): 367-371, 2008

2. Campbell DN, Liechty RD, Rutherford RB: Traumatic thrombosis of the inferior vena cava. J Trauma 21:413-415, 1987
3. Dabasia H, Rahim N, Marshall R: Neurogenic claudication without spinal stenosis arising as a result of lumbar epidural varices. J Bone Joint Surg Br 94(9):1292-1294, 2012

4. Dickman CA, Zabramski JM, Sonntag VKH, Coons S: Myelopathy due to epidural varicose veins of the cervicothoracic junction. J Neurosurg 69: 940-941, 1988

5. Endres S: Epidural Varicosis as a possible cause of radicular pain: A case report. J Med Case Reports 5: 537, 2011

6. Hanley EN Jr, Howard BH, Brigham CD, Chapman TM, Guilford WB, Coumas JM: Lumbar epidural varix as a cause of radiculopathy. Spine 19: 2122-2126, 1994

7. Paksoy Y, Gormus N: Epidural venous plexus enlargements presenting with radiculopathy and back pain in patients with inferior vena cava obstruction or occlusion. Spine 29: 24192424, 2004

8. Paldor I, Gomori JM, Lossos A, Yatsiv I, Cohen JE, Itshayek E: Intradural lumbar varix resembling a tumor: Case report of a magnetic resonance imaging-based diagnosis. Spine (Phila Pa 1976) 35(17): E864-866, 2010

9. Pekindil G, Yalniz E: Symptomatic lumbar foraminal epidural varix. Case report and review of the literature. $\mathrm{Br} J$ Neurosurg 11: 159-160, 1997

10. Sahinoglu $M$, Cetinalp NE, Divanlioglu $D$, Yildirim $A E$, Belen AD: Lomber disk hernisini taklit eden tromboze lomber epidural varis: Olgu sunumu. Türk Nöroşirürji Dergisi 24(1): 43-45, 2014

11. Slin'ko El, Al-Qashqish II: Surgical treatment of lumbar epidural varices. J Neurosurg Spine 5: 414-423, 2006

12. Tofuku K, Koga H, Yone K, Komiya S: Spontaneous regression of symptomatic lumbar epidural varix: A case report. Spine (Phila Pa 1976) 32(4): E147-149, 2007 